16 a 18 de outubro de 2019 - Campinas | Brasil

\title{
GINÁSTICA RÍTMICA MASCULINA: olhares sobre essa prática no Brasil
}

\author{
João Jacinto da Silva Neto*, Tabata Larissa Almeida Kikuti, Laurita Marconi Schiavon
}

\begin{abstract}
Resumo
A Ginástica Rítmica, atualmente organizada pela Federação Internacional de Ginástica (FIG) é um esporte que nasce e se apresenta pela prática de mulheres, indo na contramão da maioria dos esportes (RUSSO, 1993). Sua vertente masculina (GRM) faz parte de um cenário ainda incerto nacional e internacionalmente, em desenvolvimento mas ainda com pouca visibilidade. No Brasil encontramos pouco investimento e muita dificuldade em conseguir informações sobre a modalidade. Portanto, a finalidade desta pesquisa é analisar o desenvolvimento da GRM no estado de São Paulo, com enfoque nas potencialidades e dificuldades dessa modalidade esportiva. Para isso, desenvolveu-se uma pesquisa qualitativa, por meio de questionário semiestruturado com nove ginastas masculinos. Os dados foram organizados através de Análise de Conteúdo, apresentando seis categorias. A pesquisa aponta barreiras a serem superadas pelo esporte, com iniciativas ainda individuais e pouco institucionalizadas.
\end{abstract}

\section{Palavras-chave:}

Ginástica Rítmica; Gênero; Esporte.

\section{Introdução}

Ginástica Rítmica, atualmente organizada pela Federação Internacional de Ginástica (FIG) é um esporte que nasce e se apresenta pela prática de mulheres, indo na contramão da maioria dos esportes (RUSSO, 1993). Sua vertente masculina (GRM) faz parte de um cenário ainda incerto nacional e internacionalmente, em desenvolvimento, mas ainda com pouca visibilidade. No Brasil encontramos pouco investimento e muita dificuldade em conseguir informações sobre a modalidade.

Objetivo: analisar o desenvolvimento da Ginástica Rítmica Masculina (GRM) no estado de São Paulo, com enfoque nas potencialidades e dificuldades dessa modalidade esportiva.

Método: pesquisa bibliográfica e questionário semiestruturado com nove ginastas masculinos da GR do estado de São Paulo.

\section{Resultados e Discussão}

Para organização dos dados utilizamos a técnica de análise de conteúdo (BARDIN, 2011), da qual sugiram seis categorias:

1. Relações interpessoais: a convivência positiva explicitada pelos ginastas demonstra que a presença deles é vista como desejável pelas ginastas e pelas treinadoras da GR feminina.

2. Permanência e persistência no esporte: vínculos construídos entre os ginastas estabelecem uma relação com o tempo na prática. Tal fator contribui para que permaneçam no esporte, pois dizem receber apoio das colegas de treino e treinadores.

3. Influências na construção de identidades da GRM: encontramos duas linhas diferentes de GRM, o modelo espanhol e o modelo japonês. No Brasil não há um consenso entre qual linha é adotada. As competições apresentam um regulamento próprio, descrito por um dos atletas como "uma tentativa de deixar a prática menos 'feminina"'. Os meninos executam provas que reafirmam essas expectativas para o corpo masculino. Desse modo, ao praticar uma modalidade que é vista como feminina, assumirá uma postura mais delicada e será estereotipado como um ser "efeminado", desqualificando o padrão hegemônico de masculinidade (CONNELL, 1997; 2000 apud FIALHO, 2006).
4. Perspectivas de desenvolvimento no estado de SP e no Brasil: alinhadas em sua maioria às ligas, federações e instituições privadas, com poucas iniciativas de inclusão no âmbito competitivo. Os resultados das competições demonstram pouca participação de meninos (maioria individual). São citadas cinco equipes de GRM e 18 campeonatos entre 2009 e 2018.

5. Coexistência de competições de GR masculina em SP: as modalidades coexistem pela articulação realizada com as competições femininas, porém são mencionados dois torneios masculinos especificamente.

6. Políticas de inserção de meninos em competições de GR: as estruturas que são responsáveis pela modalidade no país e no mundo não organizam o masculino, sendo essa uma das dificuldades e contestações por parte dos ginastas.

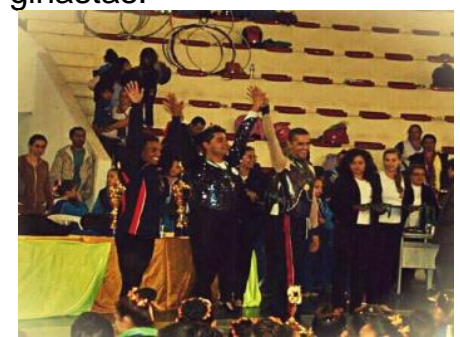

Figura 1. Pódio de uma competição de GR masculina em SP. Fonte: arquivo pessoal do participante da pesquisa.

\section{Conclusões}

Existem poucos torneios específicos para meninos no estado de SP. A GRM possui barreiras a serem superadas, portanto, é importante que exista por parte dos técnicos, professores, atletas, dirigentes, federações, uma busca em reconhecer esse esporte na sua forma masculina também. As iniciativas são ainda individuais e pouco institucionalizadas.

\section{Agradecimentos}

Ao Programa Institucional de Bolsas de Iniciação Científica/ Conselho Nacional de Pesquisa.

BARDIN, L. Análise de conteúdo. São Paulo: Edições 70, 2011

RUSSO, R. GRD Masculina, Perspectiva ou Mito? 1993. Monografia (Especialização) - Curso de Psicomotricidade e Pedagogia do Movimento, Universidade Gama Filho, Rio de Janeiro, 1993.

FIALHO, F.M. Uma crítica ao conceito de masculinidade hegemônica. Disponível em: <http://www.ics.ul.pt/publicacoes/workingpapers/wp2006/wp20 06_9.pdf>. Acesso em: 04 dez. 2017. 